\title{
GENDER DIFFERENCES IN MOBILE PHONE USAGE FOR LANGUAGE LEARNING, ATTITUDE, AND PERFORMANCE
}

\author{
Marites Piguing HILAO \\ Language Institute, Bangkok University \\ Bangkok, Thailand \\ Saovapa WICHADEE \\ Language Institute, Bangkok University \\ Bangkok, Thailand
}

\section{ABSTRACT}

Mobile phone technology that has a huge impact on students' lives in the digital age may offer a new type of learning. The use of effective tool to support learning can be affected by the factor of gender. The current research compared how male and female students perceived mobile phones as a language learning tool, used mobile phones to learn English and developed their learning performance. A five-point rating scale questionnaire was used to collect data from 122 students, comprising 65 females and 57 males. They were enrolled in a fundamental English course where mobile phone usage was integrated in certain language learning tasks with an aim to facilitate learning. The findings demonstrated that male and female students did not differ in their usage, attitudes toward mobile phone uses for language learning as well as their learning performance at a significance level. In addition, the constraints of using mobile phone for learning that students identified in an open-ended question included the small screen and keyboard the most, followed by intrusiveness of SMS background knowledge, and limited memory of mobile phone. The implication for classroom practice was proposed in how mobile phone can be fully incorporated into the instructional process in order to enhance learner engagement. The results of this study are important for teachers when implementing the mobile phone technology in language teaching. They can be used as a guideline of how mobile phone can be fully incorporated into the instructional process in order to enhance learner engagement.

Keywords: M-learning, mobile phone use, classroom teaching, higher education, mobile technology.

\section{INTRODUCTION}

According to Cavus (2011), the brisk advancement of new technologies makes change in the educational practice inevitably. Mobile learning or m-learning is identified by Lan and Sie (2010) as a new type of learning model which allows learners to receive learning materials without limitation of time and place through wireless telecommunication network and the Internet. The tools used to support m-learning include mobile technologies such as notebook computers, portable computers, Tablet PC, and cell phones. This concept is consistent with Low and O'Connel (2006) who state that mobile learning increases flexibility and gives feelings of freedom to students. As such, the changing roles of teachers in mobile learning are emphasized on the ability to use required mobile tools and technologies, being advisor or facilitator, eliminating the barriers which may occur, and creating materials or activities to increase motivation of learners. 
The involvement of mobile technologies in education has occurred in many disciplines and contexts, including the field of language teaching. The use of handheld computers or mobile phones to support language learning is called "mobile-assisted language learning" or MALL. According to Kukulska-Hume (2009), MALL has attracted much attention since it is a new type of learning environment containing at least three factors of mobility comprising technology, learner, and content. MALL differs from computer-assisted language learning in that it uses personal portable device, has continuous access, and creates communication across diverse contexts of application (Kukulska-Hume \& Shield, 2008). The importance of MALL is correspond with what Chinnery (2006) predicted in that mobile-assisted language learning would certainly appear in future language learning research.

Among many mobile technologies, mobile phones have a potential of improving the teaching and learning processes as they contain useful applications. Learning through mobile phone can occur anywhere and anytime (Brown, 2008). It is very easy to create a more useful learning environment if students either have a Blackberry or some other types of communication device. Also, they are cheap when compared to other ICTs, and everyone can afford them. Mobile devices such as Wi-Fi, Bluetooth, Short Message Services (SMS) and camera can be applied for various educational practices (Kizito, 1012). Hoppe (2009) states that students can read materials such as e-books and can watch lecture on mobile phones. According to Kafyulilo (2012), downloading feature on mobile phones can be used to get various kinds of materials and video. In addition, most of the mobile phones have features which can be used for recording and playing multimedia contents, so students can use a camera on mobile phone for documenting visual materials and collecting scientific data (Cuing \& Wang, 2008). With emails and even access to the Internet, mobile phones will be greatly useful for learning English.

Although mobile phones are banned in many classrooms since faculty perceive them as intrusive stuffs which may distract the learners from learning, they can be turned to be a learning device if the faculty know how to use them to accomplish learning tasks wisely. According to Valk, Rashid, and Elder (2010), mobile phones have been found to be effective in improving educational outcomes because it (a) improves access to education and (b) promotes learning that is learner-centered, personalized, collaborative, situated, and ubiquitous. There is some evidence that mobile phones can create pleasant learning environment and have a positive effect (Cobcroft, Towers, Smith, \& Bruns, 2006; SerranoSantoyo \& Organista-Sandoval, 2010). Various studies have investigated student's readiness, attitude and perceptions towards mobile learning by using quantitative method (Al-Fahad, 2009; Donaldson, 2011; Rahamat, Shah, Din, \& Aziz, 2011) and the findings demonstrated satisfactory outcomes.

According to Mitra, Willyard, Platt \& Parsons (2005), technologies are not utilized in similar ways by males and females and as a result some differences still existed. Previous studies indicate that females are more likely to develop mobile phone involvement (Beranuy, Oberst, Carbonell, \& Chamarro, 2009; Billieux, Van Der Linden, \& Rochat, 2008; Grellhesl \& Punyanunt-Carter, 2012; Hong, Chiu, \& Lin, 2012, Walsh, White, Cox, \& Young, 2011). However, no differences in how males and females used mobile phones were found in many studies (Bianchi \& Phillips, 2005; Junco, Merson, \& Salter, 2010; Lemish \& Cohen, 2005). So, there is still a great deal of disagreement among various studies. With regard to attitudes toward mobile phone, one study reported that female college students possessed more positive attitudes than males (Zhang, 2002) while another study revealed the opposite result (Muhanna \& Abu-Al-Sha'r, 2009). A study did not find any significant impact of gender on attitudes (Kwon \& Chidambaram, 2000).

Mobile phones have surpassed the initial purpose as a communication device. They have become a learning tool for language progress to users. Since the combination of technology and pedagogy is believed to make better learning outcomes, the current study was conducted to elicit answers from EFL students regarding the usage of this technology in learning English and attitudes when an English course integrated mobile phones into 
classroom activities. Since gender is found to have an impact on these variables in the literature review, the current study explores how males and females accept the exploitation of technology for language learning through a survey of attitude and usage. Even though there was only one study which investigated the performance as result of mobile phone usage based on gender (Omede \& Achor, 2015), the current study aimed to compare how well the two groups performed in the given tasks. The four research questions guiding this study included:

$>$ Do male and female students differ in their usage of mobile phone for language learning?

> Do male and female students differ in their attitudes toward using mobile phone for language learning?

$>$ Do male and female students differ in their learning performance?

$>$ Do students encounter any obstacles when they use mobile phone for language learning?

\section{Research Hypotheses}

$>\quad$ There is a statistically significant difference in mobile phone usage for language learning between males and females.

$>$ There is a statistically significant difference in attitude toward using mobile phone for language learning between males and females.

$>$ There is a statistically significant difference in learning performance between males and females after taking this course.

\section{METHODOLOGY}

\section{Participants}

This study took place at a private university in Thailand where the course of Fundamental English II was provided for the first-year students across faculties. It was a 3-unit credit course that met three hours weekly within a 14-week period. This course was designed to develop student's vocabulary, grammar, and reading and writing skills. For listening, pronunciation and conversation skills, students will have a chance to practice them through the use of the computerized self-study language laboratory. One hundred and twelve students, from three sections, enrolled in Fundamental English II in the second semester of 2013 academic year participated in the research. There were 65 females and 57 males. They were taught by the same instructor. All of them completed the course requirement (i.e., did all assignments and took part in an in-class test). All participants signed consent forms, and the instructor assured them that all data would be confidential and that the survey responses would not influence course grades.

\section{Personal Data}

As for the demographic information, 57 participants were male while 65 participants were female. All of them took mobile phones to class. Of the total participants, 108 participants reported their experience of using their mobile phones for academic purposes while 14 participants did not have this experience, but used them for other purposes such as communicating with others, taking photos, playing games and surfing the Internet for pleasure.

\section{Research Design}

The current study employed the theoretical framework of Vygotsky's social constructivism which had an emphasis on the role of social interaction in learning and on the concepts underlying the communicative approach in L2 learning (Vygotsky, 1978). As Craig (2009) puts up, the learning theory can be integrated with mobile learning. Since the constructivist approach indicates that people can build up their own experiences when they develop their own personal world of information sharing, there is a need to find out whether mobile technology integration, along with the constructivist approach to learning, is a perfect match. This study used quantitative analysis to investigate students' 
mobile phone usage for language study and their attitudes towards mobile phones for language learning focusing on gender.

\section{Learning Procedure}

Prior to the implementation of mobile-assisted language learning, I made a survey to see how many students carried a mobile phone to class as well as what brand they were using. The results showed that students were ready to adopt the cell phone for class work since all of them had mobile phones, 86 of which were smart phones and 36 were nonsmart phones. Moreover, our university has provided a free Wi-Fi for students and faculty members. Therefore, I decided to adopt an m-learning system in a fundamental course as a case study. All learning tasks were adjusted in order that students would have a chance to deploy mobile phones for language learning. The full score was $\mathbf{4 0}$ points.

All students in the class had mobile phones with wireless networking capabilities and both classrooms were equipped with Wi-Fi. The class was conducted based on the course syllabus designed to promote learner-centeredness. About $60 \%$ of class time was devoted to reading and writing activities while $40 \%$ of class time was spent on discussions, speaking, and presentation. There were four activities to be done in class which focused on the use of mobile phone:

$>$ Word power activity: Each week, students were given 10 new English words which they needed to handwrite along with meanings in English and Thai in an A4-sized notebook and made up a sentence for each word. To earn 10 points, they were required to do this activity in class. Students were allowed to use online dictionaries in their mobile phone to find good examples. This activity covered 10 weeks. The total number of vocabulary would be 100 words.

$>$ Summary writing activity: Students had to read a passage containing about 250 words and wrote a summary after they had learned basic rules of writing good summaries. While reading, students were encouraged to look up the meanings of unknown words from online dictionary via mobile phones. They needed to understand the story and grasped the main ideas before writing a summary. There were two pieces of summaries students had to do for this activity to gain 10 points.

> Creative writing activity: After students studied the lessons in the textbook, they chose ten words to make a story. While doing the assignment, they were able to use cell phones to access online dictionary in order to check how sentences could be made. There were two pieces of writing which totaled 10 points.

$>\quad$ The last activity was related to students' speaking performance. Students were required to make a presentation about steps to do something to earn 10 points. They were allowed to download information relating the topic they chose from the websites and used it to prepare a draft in class. Before a presentation would be done, students were suggested to check pronunciation from online dictionary. The total score was 10 points.

Apart from the four activities that demonstrated the pedagogical use of mobile phones, students had to use their mobile phone for other academic purposes such as checking emails, communicating with peers and teacher in LINE group, studying materials and the course content in LMS, text messaging through SMS, and sharing files in Google Drive. The use of mobile phone for language learning was not limited only in-class; students were encouraged to use their phone to facilitate language learning outside class too. However, it was rather difficult to control the tool they used at home. For instance, they might use a PC instead of mobile phone if they perceived more convenient.

\section{Instrument}

The instrument in this study was a questionnaire which consisted of four main parts. The first part asked the participants to give their background information comprising gender, type of mobile phone they were using, and their experience of using mobile phone in the 
study. The second part asked students about their actual use of mobile phone for language learning comprising 10 items with a choice of five rating scale responses (5= always to $1=$ never). The third part surveyed students' attitudes towards the use of mobile phone for language learning. It comprised 7 items with a choice of five rating scale responses $(5=$ strongly agree to $1=$ strongly disagree). The last part contained an open-ended question asking if students encountered any obstacles to using mobile phone technology for language learning. This issue is considered important because the shortcomings might cause the pedagogical use of mobile phones ineffective.

The Likert scales items in part 2, 3 were checked for their content validity by three experts in the English teaching field. All of the items had IOC index higher than 0.6 , so they were acceptable. In order to test the proper reliability, the questionnaire was piloted with $\mathbf{4 0}$ undergraduate students who were not the target group and calculated by using Cronbach's Alpha. According to Cronbach and Shevelson (2004), coefficient ranges in value from 0 to 1 . The higher the score, the more reliable the generated scale is. They have also indicated 0.7 to be an acceptable reliability coefficient. Two parts in the questionnaire yielded acceptable coefficient-alpha estimates with the reliability value of .92 , and .87 warranted the use for the purposes of this research study (Cronbach, 1951).

Both the students' actual use of mobile phones for language learning and attitudes towards the use of mobile phone for language learning were investigated after they studied in this course. After the questionnaires were collected, quantitative data were statistically analyzed by SPSS/Window program. Regarding non-parametric data, the Mann-Whitney $U$ tests were employed to answer the first and second research questions. Students' learning performance was evaluated from the scores received. An independent samples t-test was used to compare the mean score of performance based on gender. The acceptable statistical significance level was set at alpha $(a)<0.05$. To answer the last research question, the replies from the open-ended question were categorized and counted in numbers.

\section{RESULTS}

Research Question 1: Do male and female students differ in their usage of mobile phone for language learning?

After taking the course, students were given the survey of using mobile phone for language learning. According to Table 1, it is noteworthy that female students used mobile phone for learning more than male students in six items including number $1,2,3$, 5,6 , 9. It is interesting to see that both groups equally used Line Application on mobile phone to connect teacher and peers $(\bar{x}=3.83)$. For male students, the first highest mean score fell on item no. 10 (using online dictionary, $\bar{x}=4.13$ ), followed by item no. 5 (talking with teacher and peers about study, $\bar{x}=4.06$ ), and item no. 4 (using LINE application on mobile phone to contact the teacher and peers, $\bar{x}=3.83$ ). The lowest mean score of usage was item no. 7 (using SMS, $\bar{x}=3.30$ ). For female students, the first highest mean score fell on no. 5 (talking with teacher and peers about study, $\bar{x}=4.13$ ), followed by item no. 10 (using online dictionary, $\bar{x}=4.09$ ), and item no. 9 (taking photos and recording information for study, $\bar{x}=3.94$ ). The lowest mean score was on the same item as male chose (no.7, using SMS, $\bar{x}=3.29$ ). To answer research question 2 , a comparison of mobile phone usage was made based on gender, using Mann-Whitney $U$ tests. Results revealed that male and female students did not differ significantly in how they used their mobile phone for study in all items $(p>.05)$. Therefore, Hypothesis 1 stating that a significant difference existed in usage of males and females was rejected. 
Table 1. Comparison of mobile phone usage between male and female students

\begin{tabular}{|c|c|c|c|c|}
\hline Mobile Phone Usage & Gender & $\overline{\mathrm{X}}$ & $\mathbf{Z}$ & $\begin{array}{c}\text { p- } \\
\text { value }\end{array}$ \\
\hline \multirow{2}{*}{$\begin{array}{l}\text { 1. I searched and downloaded information from } \\
\text { websites on my mobile phones in order to do } \\
\text { assignments. } \\
\text { 2. I used LMS on my mobile phone for my study. }\end{array}$} & $\begin{array}{l}\text { Male } \\
\text { Female }\end{array}$ & $\begin{array}{l}3.47 \\
3.68\end{array}$ & $-\overline{1} \cdot 224$ & .221 \\
\hline & $\begin{array}{l}\text { Male } \\
\text { Female }\end{array}$ & $\begin{array}{l}3.51 \\
3.70\end{array}$ & $\overline{1.227}$ & .220 \\
\hline $\begin{array}{l}\text { 3. I used Facebook on my mobile phone to communicate } \\
\text { with my teacher and peers. }\end{array}$ & $\begin{array}{l}\text { Male } \\
\text { Female }\end{array}$ & $\begin{array}{l}3.77 \\
3.81\end{array}$ & -.174 & .862 \\
\hline $\begin{array}{l}\text { 4. I used Line Application on my mobile phone to } \\
\text { connect my teacher and peers. }\end{array}$ & $\begin{array}{l}\text { Male } \\
\text { Female }\end{array}$ & $\begin{array}{l}3.83 \\
3.83\end{array}$ & -.011 & .991 \\
\hline $\begin{array}{l}\text { 5. My mobile phone was used for talking with teacher } \\
\text { and peers about exercises and class activities. }\end{array}$ & $\begin{array}{l}\text { Male } \\
\text { Female }\end{array}$ & $\begin{array}{l}4.06 \\
4.13\end{array}$ & -.488 & .626 \\
\hline $\begin{array}{l}\text { 6. I used Google Drive on my mobile phone to share } \\
\text { information resources. }\end{array}$ & $\begin{array}{l}\text { Male } \\
\text { Female }\end{array}$ & $\begin{array}{l}3.64 \\
3.87\end{array}$ & $\overline{1}-666$ & .096 \\
\hline $\begin{array}{l}\text { 7. I used SMS to deal with my study (e.g. sending } \\
\text { homework, asking about assignments) }\end{array}$ & $\begin{array}{l}\text { Male } \\
\text { Female }\end{array}$ & $\begin{array}{l}3.30 \\
3.29\end{array}$ & -.326 & .745 \\
\hline 8. My mobile phone was used to check e-mails. & $\begin{array}{l}\text { Male } \\
\text { Female }\end{array}$ & $\begin{array}{l}3.81 \\
3.77\end{array}$ & $-\overline{1.916}$ & .045 \\
\hline $\begin{array}{l}\text { 9. My mobile phone was used to take photos and record } \\
\text { information for my study. }\end{array}$ & $\begin{array}{l}\text { Male } \\
\text { Female }\end{array}$ & $\begin{array}{l}3.66 \\
3.94\end{array}$ & -.280 & .779 \\
\hline $\begin{array}{l}\text { 10. I accessed on-line dictionaries in my mobile phone } \\
\text { to look up new words. }\end{array}$ & $\begin{array}{l}\text { Male } \\
\text { Female }\end{array}$ & $\begin{array}{l}4.13 \\
4.09\end{array}$ & -.172 & .863 \\
\hline
\end{tabular}

Research Question 2: Do male and female students differ in their attitudes toward using mobile phone for language learning?

Table 2 compared male and female students' attitudes toward using mobile phone for language learning after taking the course. For males, the third highest mean scores fell on item no. 5 (improving foreign language performance, $\bar{x}=3.89$ ), item no. 3 (accomplishing learning tasks more quickly, $\bar{x}=3.42$ ), and item no 7 (being useful for study, $\bar{x}=3.30$ ). The lowest mean score of attitudes was on item no. 1 (being fun, $\bar{x}=3.00$ ).

The third highest mean scores of females' attitudes were item no. 5 (improving foreign language performance, $\bar{x}=3.81$ ), followed by item no. 3 (accomplishing learning tasks more quickly, $\bar{x}=3.43$ ), and item no. 7 (being useful for study, $\bar{x}=3.29$ ). The lowest mean score was on item no. 2 (giving control over learning, $\bar{x}=2.93$ ).

It is clearly that male and female students had similar mean scores in all items. In order to find out whether a difference in attitudes toward using mobile phone for language learning existed between males and females after taking this course, Mann-Whitney $U$ tests were conducted. The results from data analysis indicated that there was no difference in attitudes between males and females in all items at a significance level of .05. Therefore, Hypothesis 2 was rejected. 
Table 2. Comparison of attitudes toward mobile phone usage based on gender

\begin{tabular}{|c|c|c|c|c|}
\hline Attitudes & Gender & $\overline{\mathrm{X}}$ & $\mathbf{Z}$ & p-value \\
\hline $\begin{array}{l}\text { 1. Learning on the mobile phone created a } \\
\text { pleasant learning environment. }\end{array}$ & $\begin{array}{l}\text { Male } \\
\text { Female }\end{array}$ & $\begin{array}{l}3.00 \\
3.07\end{array}$ & -.349 & .727 \\
\hline $\begin{array}{l}\text { 2. Learning on the mobile phone gave me } \\
\text { more control over my learning. }\end{array}$ & $\begin{array}{l}\text { Male } \\
\text { Female }\end{array}$ & $\begin{array}{l}3.06 \\
2.93\end{array}$ & $\overline{1} .084$ & .278 \\
\hline $\begin{array}{l}\text { 3. Learning on the mobile phone enabled me } \\
\text { to accomplish learning tasks more quickly. }\end{array}$ & $\begin{array}{l}\text { Male } \\
\text { Female }\end{array}$ & $\begin{array}{l}3.42 \\
3.43\end{array}$ & -.102 & .919 \\
\hline $\begin{array}{l}\text { 4. Learning through mobile phone enabled } \\
\text { me to solve language problems. }\end{array}$ & $\begin{array}{l}\text { Male } \\
\text { Female }\end{array}$ & $\begin{array}{l}3.21 \\
3.19\end{array}$ & -.186 & .853 \\
\hline $\begin{array}{l}\text { 5. Learning on the mobile phone helped me } \\
\text { develop my language performance. }\end{array}$ & $\begin{array}{l}\text { Male } \\
\text { Female }\end{array}$ & $\begin{array}{l}3.89 \\
3.81\end{array}$ & -.755 & .450 \\
\hline $\begin{array}{l}\text { 6. Learning on the mobile phone made } \\
\text { learning language easier. }\end{array}$ & $\begin{array}{l}\text { Male } \\
\text { Female }\end{array}$ & $\begin{array}{l}3.21 \\
3.20\end{array}$ & -.011 & .991 \\
\hline $\begin{array}{l}\text { 7. I found learning on the mobile phone } \\
\text { useful for my study. }\end{array}$ & $\begin{array}{l}\text { Male } \\
\text { Female }\end{array}$ & $\begin{array}{l}3.30 \\
3.29\end{array}$ & -.064 & .949 \\
\hline
\end{tabular}

Research Question 3: Do male and female students differ in their learning performance?

Table 3. Comparison of scores based on gender

\begin{tabular}{lcccc}
\hline Gender & $\bar{X}$ & S.D. & t & p-value \\
\hline Male & 29.79 & 3.57 & 1.73 & .085 \\
Female & 28.75 & 3.03 & & \\
\hline
\end{tabular}

Students' performance scores gained from the four tasks were taken to analyze based on their gender. From the total score was $\mathbf{4 0}$ point, the average score that male students received was 29.79 while female students had the average score of 28.75 . When the $t-$ test was taken to analyze, it was found that male and female students did not differ in their learning performance. As a result, Hypothesis 3 was not accepted.

Research Question 4: Do students encounter any obstacles when they use mobile phone for language learning?

Students were asked to reply in an open-ended question about obstacles to using of mobile phone in their study. The finding revealed that 49 from 122 students did not find any obstacles in their learning. So, Seventy-three students who had obstacles were further asked to specify any constraints they encountered during the coursework. The findings showed that they identified the small screen and keyboard the most $(65.75 \%)$, followed by intrusiveness of SMS background knowledge $(43.83 \%)$ and limited memory of phone $(17.81 \%)$. A nearly equal number $(12.33 \%)$ stated that the university wifi was limited. A connection was not good. They often lost connection when they were doing the activity. Five students $(6.85 \%)$ found it difficult to adapt themselves to learning through mobile phone technology. Only two students $(2.74 \%)$ complained that they had to do a lot of activities using mobile phone. 
Table 4. Number and percentage of students identifying the obstacles

\begin{tabular}{lcc}
\hline \multicolumn{1}{c}{ Obstacle } & Number & Percentage \\
\hline The small screen and keyboard & 48 & 65.75 \\
Intrusiveness of SMS & 32 & 43.83 \\
Limited memory & 13 & 17.81 \\
Ineffectiveness of University's Wi-Fi & 9 & 12.33 \\
inadaptability to this learning process & 5 & 6.85 \\
Too many activities to be done on mobile phone & 2 & 2.74 \\
\hline
\end{tabular}

\section{DISCUSSION}

The first discussion is on students' usage of mobile phone for language learning. The two highest mean scores of items male and female students chose for their usage were the same. These items really reflected benefits of mobile phone to facilitate their learning. They communicate with peers and teachers using LINE and use online dictionary so as to understand new words. This indicates that mobile phones have a potential of improving the teaching and learning processes as they contain useful applications. In addition, the usage of mobile phone in this course aims at enabling the learners to develop themselves at their own pace and to the best of their potentiality. Therefore, the course activities might help reinforce the usage. The functionality of advanced mobile phones provides more choices of activities to be designed for improving students' language proficiency. Also, it was found that male and female students did not differ in their usage. This is probably because all students had to do the activities to fulfill the requirement of this course. The finding was in accordance with some previous studies (Bianchi \& Phillips, 2005; Junco et al., 2010; Lemish \& Cohen, 2005) in that there were no differences in how males and females used mobile phones.

The next discussion will be on the attitudes toward mobile usage. Interesting, male and female students expressed the same for the third highest mean scores. These are 1) improving language performance, 2) completing learning tasks more quickly, and 3) being useful for study. Based on the results from Mann-Whitney $U$ tests, male and female students did not differ in their attitudes after taking the course at a significance level. This is probably students similarly gained experience of how mobile phones were used for language learning through specifically designed activities. Moreover, students were encouraged to use mobile phones for other academic purposes such as checking e-mails, communicating with peers and teacher in LINE group, studying materials and the course content in LMS, text messaging through SMS, and sharing files in Google Drive. Therefore, the current study presented the similar results to previous studies which also found students' positive attitudes and perceptions toward mobile learning (Al-Fahad, 2009; Donaldson, 2011; Rahamat et al., 2011). In addition, male and female students did not differ in their attitudes toward using mobile phone for language learning. This is probably because students can see the potentials of mobile phone in enhancing various activities in the English course. Not only they gain a new learning experience, they realize that they can improve the language proficiency with this technological tool. It can be concluded that gender has no impact on students' attitude. The finding is found to be consistent to that of the study conducted by Kwon \& Chidambaram (2000).

Also, the study did not find any difference in males and females' learning performance. The result for the third research question was not surprising since the attitudes and usage of the two groups were not different, their learning performance was the same too. This is due to the fact that all of the tasks were done in class. The students had to complete the tasks within the given time. The teacher acted as a facilitator who helped them when they had problems. Based on the researcher's observation, they paid much attention to the work they were doing. The course was designed to be activity-based. Students realized that they could gain a lot of points from these tasks, it was better for them to do 
their best. These scores could help them in case they failed in their exam. The current finding was found to be consistent to the previous study conducted by Omede and Achor (2015) identifying that there was no significant difference in males and females' learning performance.

Based on the findings, students had encountered a number of obstacles. In this regard, the limitation of small screen and keyboard was identified the most. One of the reasons they stated this limitation is probably because many activities were related to typing the keyboard. For instance, students had to look up new words from online dictionary. In designing the future course, it is better to avoid any activity requiring them to type on keyboard. More activities can be focused on displaying video clips since the full color of most screens is now really quite good. The study also found that since students were encouraged to use SMS to ask or consult their friends about assignments, many of them felt disturbed by SMS. However, students did not mention the intrusiveness of messages they received in LINE group. Such finding is noteworthy; means of communication might have an impact on students' attitude toward mobile technology use. So, this issue should be taken into account too.

\section{IMPLICATION FOR PRACTICE}

The present study makes several contributions to the area of language teaching. It provides how mobile phone technology can be used for language proficiency development. It would be beneficial for concerned people in developing a future course as follows:

$>$ Since gender has no impact on students' attitude and usage of mobile phone for language learning, learning tasks can be prepared more easily. However, students should be more motivated to make use of learning on the mobile phone since the levels of attitude and usage are not high in this study. It is the teacher's duty to make students see benefits from those tasks rather than perceive them as a big burden.

$>$ When mobile phone is implemented in class, teachers should design the learning tasks that will really suit the capability of the phones that students have. For instance, students may not carry advanced mobile phones or they do not have certain applications. So, it is the teachers who will explore the readiness before real use. It is better to check the availability of applications or services in their cell phones. Running certain activities might not be possible if students don't have applications on their cell phones. Otherwise, students may develop a negative attitude toward using the mobile phone technology for educational purposes.

$>$ Realizing the role technologies are playing in the teaching and learning process, the university administrators should place more importance on the combination of mobile technologies and pedagogy in language classes. Teachers should have more training to update their knowledge of how to implement those technologies into their teaching. This will help them to arrange the learning tasks more effectively with good support from mobile technologies.

\section{BIODATA and CONTACT ADDRESSES of AUTHORS}

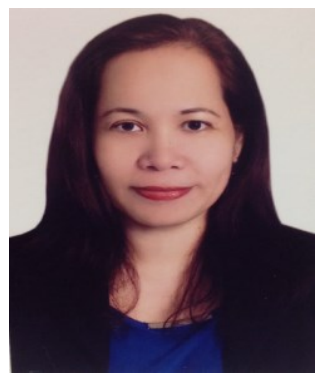

Marites Piguing HILAO is a full-time teacher with 17 years of teaching experience at Language Institute, Bangkok University. She obtained her bachelor's degree from San Ildefonso College, Philippines. Her field of interest was in English Language and Literature. She is currently working as an Assistant to Associate Director for Language Skill Development and Academic Services in Language Institute, Bangkok University, Thailand. She has presented research papers in international conferences. 
Marites Piguing HILAO

Language Institute

Bangkok University, Bangkok Thailand, 10110

Phone: (+662) 350-3500 Ext. 1680

E-mail: marites.h@bu.ac.th

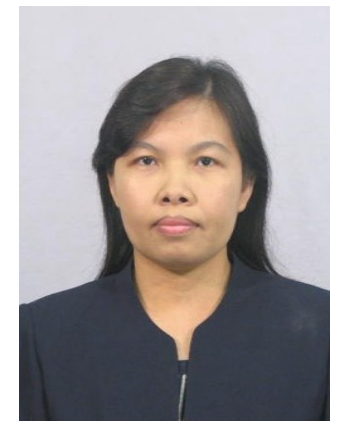

Saovapa WICHADEE is an Associate Professor of English language at Language Institute, Bangkok University. She received a Master's degree in English from Srinakharinwirot Prasarnmitr University, Thailand. Her research interests include teaching methodology in EFL, learners' characteristics, the use of technologies in teaching, and teacher self-development. Most of her latest studies focused on the use of social networks in language teaching. She has published many research articles in both national and international journals during the past five years.

\section{Saovapa WICHADEE}

Language Institute

Bangkok University, Bangkok, Thailand, 10110

Phone: (+662) 9020299 ext. 2680

E-mail: saovapa.w@bu.ac.th

\section{REFERENCES}

Al-Fahad, F. N. (2009). Students' attitudes and perceptions towards the effectiveness of mobile learning in King Saud University, Saudi Arabia. The Turkish Online Journal of Educational Technology, 8(2), 111-119.

Beranuy, M., Oberst, U. Carbonell, X., \& Chamarro, A. (2009). Problematic Internet and mobile phone use and clinical symptoms in college students: the role of emotional intelligence. Computers in Human Behavior, 25(5), 1182-1187.

Bianchi A., Phillips J. G. (2005). Psychological predictors of problem mobile phone use. Cyber Psychology Behavior, 8(1):39-51.

Billieux, J., Van Der Linden, M., \& Rochat, L. (2008). The role of impulsivity in actual and problematic use of the mobile phone. Applied Cognitive Psychology, 22(9), 11951210.

Brown, L. (2008). Using Mobile Learning to Teach Reading to Ninth-Grade Students. Ph.D dissertation Capella University, USA. Available Online at http://gradworks.umi.com/ 3330949.pdf

Cavus, N. (2011). Investigating mobile devices and LMS integration in higher education: student perspectives. Procedia Computer Science, 3, 1469-1474.

Chinnery, G. M. (2006). Going to the MALL: Mobile Assisted Language Learning. Language Learning \& Technology, 10(1), 9-16.

Cuing, G., \& Wang, S. (2008). Adoption cell phones in EFL Teaching and Learning. Retrieved October 31, 2012 from www.notworthprinting.wordpress.com/ category/mobile-learning.

Craig, T., \& Van Lorn, M. (2009). Impact Constructivist Learning Theory and MobileTechnology Integration. [Academic]. Theories of Educational Technology, 12, 1-12. 
Cobcroft, R. S., Towers, S. J., Smith, J. E., \& Bruns, A. (2006). Mobile learning in review: Opportunities and challenges for learners, teachers and institutions. In Proceedings Online Learning and Teaching (OLT) Conference 2006, (pp.21-30). Brisbane: Queensland University of Technology.

Donaldson, R.L. (2011). Student acceptance of mobile learning. Dissertation. The Florida State University College of Communication \& Information. Retrieved April 26, 2012 from http://etd.lib.fsu.edu/theses/available/etd-05312011074842/ unrestricted/Donaldson_R_dissertation_2011.pdf.

Grellhesl, M., \& Punyanunt-Carter, N. M. (2012). Using the uses and gratifications theory to understand gratifications sought through text messaging practices of male and female undergraduate students. Computers in Human Behavior, 28(6), 2175-2181.

Hong, F. Y., Chiu, S. I., \& Lin, H. Y. (2012). The development and current states of private college student mobile phone addiction scale. Chung Cheng Educational Studies, 11(1), 87-116.

Hoppe, M. (2009). Mobile learning and Education application www.pervasive. Retrieved October 31, 2012 from wiwi.unidue.de/.../hoppe_mobile-learning-and-educ/

Junco R., Merson D., \& Salter D. W. (2010). The effect of Gender, ethnicity, and income on college students' use of communication technologies. Cyber Psychology Behavior, 13(6), 619-627.

Kafyulilo, A. (2012). Access, use and perceptions of teachers and students towards mobile phones as a tool for teaching and learning in Tanzania. Retrieved October 31, 2012 from http://rd.springer.com/article/10.1007/s10639-012-9207yEducational and information technologies journal

Kizito, N.R, (2012). Pre testing Mathematical Concepts with the Mobile Phone: Implications for Curriculum Design. Retrieved October 31, 2012 from http://www.irrodl.org/index.php/irrodl/article/view/1065/2075

Kukulska-Hulme, A. (2009). Will mobile learning change language learning? ReCALL, 21(2), 157-165.

Kukulska-Hulme, A., \& Shield, L. (2008). An overview of mobile assisted language learning: From content delivery to supported collaboration and interaction. $R e C A L L, 20(3), 271-289$.

Mitra A., Willyard J., Platt C., \& Parsons, M. (2005). Exploring web usage and selection criteria among male and female students. Journal of Computer-Mediated Communication, 10 (3). Retrieved August 2, 2014 from http://jcmc.indiana.edu/vol10/issue3/mitra.html.

Kwon, S.K., \& Chidambaram, L. (2000). A Test of the Technology Acceptance Model: The Case of Cellular Telephone Adoption. In Proceedings of the 33rd Hawaii International Conference on Systems Sciences, Hawaii.

Lan, Y. F., \& Sie, Y. S. (2010). Using RSS to support mobile learning based on media richness theory. Computers \& Education, 55(2), 723-732.

Lemish, D., \& Cohen, A. (2005). On the gendered nature of mobile phone culture in Israel. Sex Roles, 52(7/8), 511-522. 
Low, L., \& O'Connel, M. (2006). Learner-centric design of digital mobile learning. Retrieved January 22, 2013 fro

http://online.cit.act.edu.au/mlearning/lowoconnell2006.pdf

Muhanna, W., \& Abu-AI-Sha'r, A. (2009). University Students' Attitudes towards Cell Phone Learning Environment. International Journal of Interactive Mobile Technologies. 3(4).

Omede, J., \& Achor, E. (2015). Gender dimensions in the use of mobile phone SMS on note taking and comprehension of audio-taped lecture materials in Kogi State of Nigeria. Research Journal of Educator, 1(1), 8-14.

Rahamat, R., Shah, P., Din, R., \& Aziz, J. A. (2011). Students' readiness and perceptions towards using mobile technologies for learning the English language literature components. Retrieved August, 31, 2012 from http://www.melta.org.my/ET/2011/69_84_Rashidah\%202011.pdf

Serrano-Santoyo, A., \& Organista-Sandoval, J. (2010, November). Challenges and opportunities to support learning with mobile devices. In Proceedings of the 3rd Mexican Workshop on Human Computer Interaction (pp.8587). Universidad Politécnica de San Luis Potosí.

Valk, J.H., Rashid, A., \& Elder, L. (2010). Using mobile phones to improve educational outcomes: An analysis of evidence from Asia. International Review of Research in Open and Distance Learning, 11(1), 117-140.

Vygotsky, L. S. (1978). Mind in society. Cambridge, MA: Harvard University Press.

Walsh, S. P., White, K. M., Cox, S., \& Young, R. M. (2011). Keeping in constant touch: the predictors of young Australians' mobile phone involvement. Computers in Human Behavior, 27(1), 333-342.

Zhang, Y. X. (2002). Comparison of Internet attitudes between industrial employees and college students. Cyberpsychology and Behavior, 5(2), 143-149. 